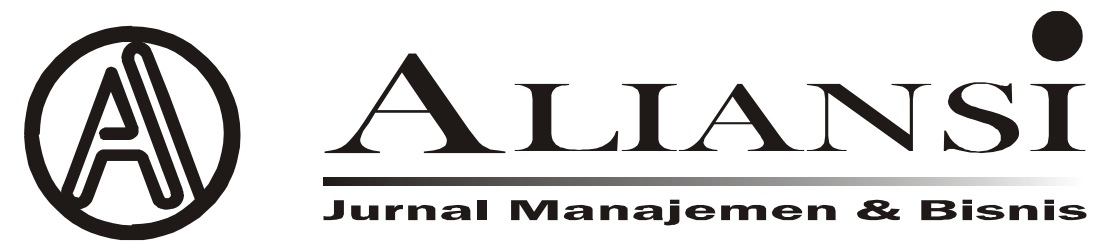

\title{
PENGARUH PELAKSANAAN PROGRAM PELATIHAN DAN PENERAPAN SISTEM MANAJEMEN K3 TERHADAP PRODUKTIVITAS KERJAANGGOTA PADA DINAS PEMADAM KEBAKARAN KOTA BEKASI
}

\author{
Oleh : Meta Luvita Sari dan Rycha Kuwara Sari
}

email : rycha.kuwara@ubharajaya.ac.id

\begin{abstract}
This research was conducted to determine whether there is an effect of the implementation of training programs and the application of occupational safety and health management systems on the work productivity of members of the Bekasi city fire department. Based on the results of the research on the Implementation of the Training Program and the Implementation of Occupational Health and Safety Management Systems (K3) on the Work Productivity of Employees at the Bekasi City Fire Department, there is an effect either partially or simultaneously. The conclusion of this study is that the Implementation of the Training Program and Implementation of the Occupational Safety and Health Management System (K3) explains the effect on the Work Productivity of Members at the Bekasi City Fire

Service by $53.8 \%$, while the rest is influenced by other independent variables that are not researched.

Keywords: Implementation of Training Programs, Implementation of Occupational Health and Safety Management Systems (K3), Work Productivity
\end{abstract}

\section{PENDAHULUAN}

Sumber daya manusia merupakan aset penting dalam menentukan keberhasilan suatu perusahaan atau organisasi. Sumber daya manusia memiliki konsep, bahwa individu merupakan motor penggerak suatu organisasi, lembaga dan perusahaan, serta merupakan aset yang harus dilatih, dikembangkan kemampuannya serta menjamin segala keperluan yang dibutuhkan anggota dalam menjalani tugas. Setiap organisasi berharap karyawan atau anggotanya dapat melakukan pekerjaan secara efektif dan menghasilkan produktivitas kerja yang optimal. Untuk mencapai keberhasilan organisasi, terdapat beberapa faktor yang perlu diperhatikan, seperti cara mengoptimalkan produktivitas kerja anggota organisasi. Oleh karena itu, organisasi perlu mengetahui bagaimana cara meningkatkan produktivitas anggotanya.

Produktivitas merupakan indikator utama bagi kemajuan sebuah organisasi, sehingga mampu bersaing dan meningkatkan laju perkembangan ekonomi perusahaan. Sering kali suatu organisasi hanya mengutamakan keberhasilannya saja, namun tidak memperhatikan cara meningkatkan kinerja tersebut. Faktor yang mempengaruhi produktivitas kerja anggota salah satunya yaitu kemampuan atau skill para anggota organisasi. Setiap anggota perlu memiliki kemampuan untuk mempermudah dalam menyelesaikan tugas, serta diperlukan peningkatan kemampuan. Oleh karena itu, organisasi perlu mengetahui cara meningkatkan kemampuan anggotanya dengan mengadakan program pelatihan untuk meningkatkan kualitas sumber daya manusia dan untuk mencapai produktivitas kerja.

Pelatihan kerja adalah proses sistematis untuk mengajarkan atau meningkatkan pengetahuan, keterampilan, sikap, dan perilaku tertentu terkait pekerjaan, sehingga karyawan menjadi lebih terampil, lebih bertanggung jawab, dan bekerja lebih baik. Pelatihan bersifat instruktif atau empiris, dan bertujuan untuk mengembangkan keterampilan, pengetahuan , atau sikap dalam perilaku untuk mencapai standar yang diharapkan.

Selain program pelatihan, perusahaan perlu memperhatikan beberapa faktor yang mempengaruhi produktivitas, seperti keselamatan dan keseatan kerja anggota. Keselamatan dan kesehatan kerja, merupakan upaya untuk menjamin kebutuhan baik jasmani maupun rohani tenaga kerja. Dalam melaksanakan tugas, setiap anggota dihadapi dengan berbagai risiko. Kecelakaan saat melakukan tugas merupakan hal yang terkadang dialami anggota, dan 
hal ini dapat menurunkan produktivitas dan menimbulkan kerugian baik material bagi organisasi dan kerusakan pada lingkungan sekitar. Oleh karena itu setiap perusahaan perlu menerapkan sistem manajemen keselamatan dan kesehatan kerja anggotanya agar tidak terjadi kecelakaan saat menjalani tugas.

Keselamatan dan kesehatan kerja (K3) sangat penting dimiliki oleh setiap perusahaan, apalagi perusahaan tersebut memiliki risiko cukup tinggi seperti yang dialami oleh para anggota dinas pemadam kebakaran kota Bekasi dalam upaya penanggulangan kebakaran. Sistem manajemen keselamatan dan kesehatan kerja dilakukan agar anggota dinas pemadam kebakaran kota Bekasi merasa aman, nyaman, sehat dan selamat dalam menjalani tugas, sehingga produktivitas kerja dapat tercapai secara optimal.

Dinas pemadam kebakaran kota Bekasi merupakan organisasi yang terdiri dari 370 anggota yang bertugas sebagai staf, memadamkan kebakaran, melakukan penyelamatan, dan menanggulangi bencana alam atau kejadian lainya yang tidak pernah terlepas dari berbagai bahaya maupun risiko yang dialami. Dinas pemadam kebakaran kota Bekasi terletak di Jalan Komodo raya no.1 Perumnas. Pada dinas pemadam kebakaran telah menerapkan program pelatihan dan keselamatan dan kesehatan kerja antara lain : (1) Program pelatihan evakuasi korban, (2) Program pelatihan tanggap darurat dalam penanggulangan kebakaran, (3) Pelatihan Pengunaan alat pemadam api, (4) Penggunaan alat pelindung diri (APD) khusus anggota pemadam kebakaran. Namun pada kenyataannya, masih saja terdapat kecelakaan yang terjadi ketika menjalankan tugas pemadam kebakaran.

Berikut adalah data kecelakaan anggota saat menjalakan tugas pada tahun 2020 sebagai berikut :

\section{Tabel 1.1}

Data Kecelakaan Anggota Pada Dinas Pemadam Kebakaran Kota Bekasi

\begin{tabular}{|c|c|c|c|c|}
\hline \multirow[b]{2}{*}{ Bulan } & \multicolumn{4}{|c|}{ Jumlah Anggota } \\
\hline & $\begin{array}{c}\text { Menghirup asap } \\
\text { beracun }\end{array}$ & $\begin{array}{c}\text { Kelalaian } \\
\text { driver }\end{array}$ & $\begin{array}{c}\text { Kecelakaan alat } \\
\text { kerja }\end{array}$ & $\begin{array}{l}\text { Jatuh dari } \\
\text { gedung }\end{array}$ \\
\hline Januari & 11 & nihil & 3 & nihil \\
\hline Februari & 16 & 1 & Nihil & 3 \\
\hline Maret & 6 & nihil & 3 & nihil \\
\hline April & 6 & nihil & 1 & nihil \\
\hline Mei & 9 & $\begin{array}{ll}\text { nihil } \\
\text { nits }\end{array}$ & 2 & 2 \\
\hline Juni & 8 & nihil & 4 & 2 \\
\hline Juli & 15 & nihil & 9 & 6 \\
\hline Agustus & 19 & nihil & 6 & 1 \\
\hline September & 17 & 2 & 4 & Nihil \\
\hline Oktober & 17 & nihil & 3 & Nihil \\
\hline November & 14 & nihil & Nihil & Nihil \\
\hline Desember & 12 & 1 & Tihil & 1 \\
\hline Total & 150 & 1 & 35 & 15 \\
\hline
\end{tabular}

Sumber : Kasie dalops pemadaman dan penyelamatan dinas pemadam kebakaran kota Bekasi
Dari data diatas, dapat disimpulkan bahwa pada tahun 2020, perusahaan memiliki tingkat kecelakaan kerja sebesar 150 kasus yang mengalami keracunan akibat asap, 4 kasus akibat kelalaian driver, 35 kasus yang mengalami kecelakaan akibat

alat kerja, dan 15 kasus yang mengalami jatuh dari gedung. Banyaknya kecelakaan yang terjadi pada tahun 2020 mengakibatkan anggota merasa keselamatan dan kesehatan kerja kurang terpenuhi dan dikategorikan tingkat kecelakaan kerja cukup tinggi.

Kasus kecelakaan tersebut diakibatkan kurangnya perlengkapan mengenai alat pelindung diri untuk para anggota dinas pemadam kebakaran. Perlengkapan tersebut digunakan untuk meminimalisir kasus kecelakaan pada anggota yang tugas tersebut tidak pernah terlepas dari berbagai macam bahaya.

Berdasarkan latar belakang permasalahan di atas, program pelatihan dan penerapan sistem keselamatan dan kesehatan kerja merupakan hal penting yang perlu di perhatikan dalam upaya meningkatkan produktivitas kerja. Oleh karena itu penulis tertarik untuk melakukan penelitian mengenai "Pengaruh Pelaksanaan Program Pelatihan Dan Penerapan Sistem Manajemen Keselamatan Dan Kesehatan Kerja (K3) Terhadap Produktivitas Kerja Anggota Pada Dinas Pemadam Kebakaran Kota Bekasi”.

\section{TINJAUAN PUSTAKA}

\section{Pelaksanaan Proram Pelatihan}

Menurut (Yusuf, 2015), pelatihan merupakan bagian dari pendidikan. Pelatihan bersifat spesifik, praktis dan segera. Spesifik berarti pelatihan behubungan dengan bidang pekerjaan yang dilakukan. Praktis dan segera berarti yang sudah dilatih dapat dipraktikkan. Umumnya pelatihan di maksudkan untuk memperbaiki penguasaan berbagai keterampilan kerja dalam waktu relative singkat.

Menurut (Sofyandi, 2013), pelatihan adalah suatu usaha untuk meningkatkan pengetahuan dan kemampuan pegawai dalam melaksanakan pekerjaanya lebih efektif dan efisien. Program pelatihan adalah serangkaian program yang dirancang untuk meningkatkan pengetahuan dan kemampuan pegawai dalam hubunganya dalam pekerjaannya, efektivitas program pelatihan adalah suatu istilah untuk memastikan apakah program pelatihan dijalankan dengan efektif dalam mencapai sasaran yang ditentukan. 
Penerapan Sistem Manajemen Keselamatan dan Kesehatan Kerja (K3)

Menurut (Suparyadi, 2015), keselamatan kerja dapat didefinisikan sebagai suatu kondisi di mana karyawan dalam melaksanakan pekerjaannya dengan terbatas dari kemungkinan terjadinya kecelakaan sehingga mereka tidak merasa khawatir akan mengalami kecelakaan. Sedangkan kesehatan kerja merupakan suatu kondisi fisik, mental, sosial dan bukan hanya ketiadaan penyakit atau kelemahan pada waktu melaksanakan pekerjaan.

Menurut (Bangun, 2017), Sistem Manajemen Keselamatan dan Kesehatan Kerja (SMK3) adalah pengoperasian fungsi-fungsi manajemen ke dalam kegiatan-kegiatan organisasi yang berkaitan dengan Keselamatan dan Kesehatan Kerja (K3).

\section{Produktivitas Kerja}

Menurut (Sutrisno, 2015), produktivitas adalah ukuran efesiensi prouduktif. Suatu perbandingan antara hasil keluaran dan masukan. Masukan sering di batasi dengan tenaga kerja, sedangkan keluaran diukur dalam kesatuan fisik, bentuk nilai.

Menurut (Widodo, 2015), produktivitas adalah hubungan antara keluaran atau hasil organisasi dengan masukan yang di perlukan. Produktivitasnya dapat dikuantifikasi dengan membagi keluaran dan masukan.

\section{Kerangka Pemikiran dan Hipotesis}

Hipotesis 1 : Diduga terdapat pengaruh positif antara pelaksanaan program pelatihan terhadap produktivitas kerja anggota pada dinas pemadam kebakaran kota Bekasi.

Hipotesis 2 : Diduga terdapat pengaruh positif antara penerapan sistemmanajemen Keselamatan dan Kesehatan Kerja (K3) terhadap produktivitas kerja anggota pada dinas pemadam kebakaran kota Bekasi.

Hipotesis 3 : Diduga terdapat pengaruh positif antara pelaksanaan program pelatihan dan penerapan sistem Keselamatan dan Kesehatan Kerja (K3) terhadap produktivitas kerja anggota dinas pemadam kebakaran kota Bekasi.

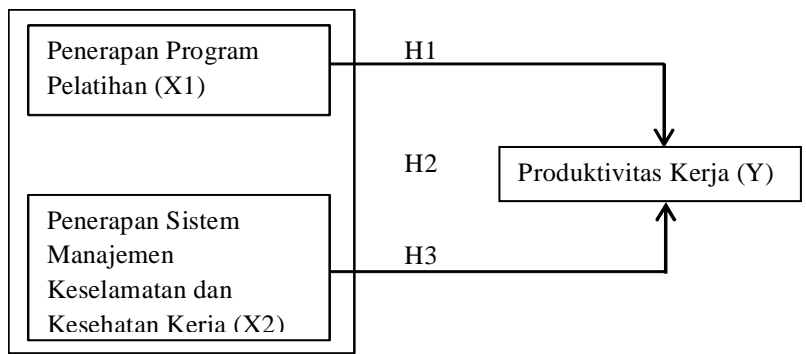

\section{METODE PENELITIAN}

Jenis penelitian yang digunakan adalah penelitian kuantitatif. Kuantitatif yaitu penelitian ilmiah sistematis yang berurusan dengan bagian- bagian dan fenomena serta kausalitas hubungan- hubungannya yang datanya berupa angka. Tujuan penelitian ini yaitu untuk mengembangkan dan menggunakan model matematika, teori dan atau hipotesis terkait fenomena. Data yang digunakan dalam penelitian ini adalah data kuantitatif.

Data yang digunakan dalam penelitian ini adalah data primer dan data sekunder. Data primer diperoleh secara langsung dari hasil observasi, wawancara dan kuesioner. Sedangkan data sekunder merupakan data yang didapatkan dari jurnal-jurnal penelitian, buku referensi, dan dokumentasi pengumpulan data pada dinas pemadam kebakaran kota Bekasi. Pada penelitian ini penulis menggunakan uji reliabilitas dan uji validitas untuk memastikan data yang digunakan valid. Data dikumpulkan dengan cara menyusun daftar pertanyaan yang akan diajukan kepada responden dalam bentuk kuesioner kemudian data yang sudah terkumpul akan diolah menggunakan program SPSS.

Sampel adalah bagian dari jumlah dan karakteristik yang dimiliki oleh populasi tersebut (Sugiyono, 2017). Sampel dalam penelitian ini adalah anggota dinas pemadam kebakaran kota Bekasi. Teknik pengambilan sampel adalah purposive sampling yang menggunakan rumus slovin, adalah sebagai berikut :

$$
n=\frac{\mathrm{N}}{1+\mathrm{Ne}^{2}}
$$

Keterangan :

n : Sampel

$\mathrm{N}$ : Populasi

e : Taraf kesalahan atau error sebesar 0,1 (10\%)

$$
\begin{aligned}
\mathrm{n} & =\frac{370}{1+(370.0,12)} \\
& =\frac{370}{1+(370.0,01)} \\
& =\frac{370}{1+(3,7)} \\
& =\frac{370}{4,7} \\
& =78,72
\end{aligned}
$$

Maka dibulatkan menjadi 79 responden.

Jenis data yang akan digunakan pada penelitian ini yaitu data primer dan data sekunder. 


\section{HASIL DAN PEMBAHASAN UJI VALIDITAS}

Tabel 4.1

Uji Validitas Pelaksanaan Program Pelatihan (X1)

\begin{tabular}{|c|c|c|c|}
\hline Korelasi antara & R hitung & R table & Kesimpulan \\
\hline Pertanyaan 1 & 0,568 & 0,2213 & Valid \\
\hline Pertanyaan 2 & 0,533 & 0,2213 & Valid \\
\hline Pertanyaan 3 & 0,544 & 0,2213 & Valid \\
\hline Pertanyaan 4 & 0,528 & 0,2213 & Valid \\
\hline Pertanyaan 5 & 0,813 & 0,2213 & Valid \\
\hline Pertanyaan 6 & 0,842 & 0,2213 & Valid \\
\hline Pertanyaan 7 & 0,835 & 0,2213 & Valid \\
\hline Pertanyaan 8 & 0,794 & 0,2213 & Valid \\
\hline Pertanyaan 9 & 0,538 & 0,2213 & Valid \\
\hline Pertanyaan 10 & 0,730 & 0,2213 & Valid \\
\hline
\end{tabular}

Sumber: Olah data SPSS 23, 2021

Nilai $r$ hitung yang didapatkan dari masing- masing pertanyaan variabel Pelaksanaan Program Pelatihan memiliki nilai $r$ hitung lebih besar daripada $r$ tabel yang memiliki nilai sebesar 0,2213 , sehingga dapat disimpulkan bahwa sepuluh butir pernyataan atau pertanyaan yang ada pada variabel pelaksanaan program pelatihan dinyatakan valid.

Tabel 4.2

Tabel Uji Validitas Penerapan Sistem Manajen Keselamatan Dan Kesehatan Kerja (X2)

\begin{tabular}{|l|c|c|c|}
\hline $\begin{array}{c}\text { Korelasi } \\
\text { antara }\end{array}$ & R hitung & R tabel & Kesimpulan \\
\hline Pertanyaan 1 & 0,727 & 0,2213 & Valid \\
\hline Pertanyaan 2 & 0,769 & 0,2213 & Valid \\
\hline Pertanyaan 3 & 0,683 & 0,2213 & Valid \\
\hline Pertanyaan 4 & 0,772 & 0,2213 & Valid \\
\hline Pertanyaan 5 & 0,704 & 0,2213 & Valid \\
\hline Pertanyaan 6 & 0,747 & 0,2213 & Valid \\
\hline Pertanyaan 7 & 0,714 & 0,2213 & Valid \\
\hline Pertanyaan 8 & 0,761 & 0,2213 & Valid \\
\hline Pertanyaan 9 & 0,686 & 0,2213 & Valid \\
\hline Pertanyaan 10 & 0,669 & 0,2213 & Valid \\
\hline
\end{tabular}

Sumber: Olah data SPSS 23, 2021

Nilai $r$ hitung yang didapatkan dari masing- masing pertanyaan variabel Penerapan Sistem Manajemen Keselamatan dan Kesehatan Kerja(K3) memiliki nilai $r$ hitung lebih besar daripada $r$ tabel yang memiliki nilai sebesar 0,2213, sehingga dapat disimpulkan bahwa sepuluh butir pernyataan atau pertanyaan yang ada pada variabel pelaksanaan program pelatihan dinyatakan valid.
Tabel 4.3

Uji Validitas Produktivitas Kerja (Y)

\begin{tabular}{|c|c|c|c|}
\hline $\begin{array}{c}\text { Korelasi } \\
\text { antara }\end{array}$ & R hitung & R table & Kesimpulan \\
\hline Pertanyaan 1 & 0,771 & 0,2213 & Valid \\
\hline Pertanyaan 2 & 0,683 & 0,2213 & Valid \\
\hline Pertanyaan 3 & 0,813 & 0,2213 & Valid \\
\hline Pertanyaan 4 & 0,669 & 0,2213 & Valid \\
\hline
\end{tabular}

Sumber: Olah data SPSS 23, 2021

Nilai $r$ hitung yang didapatkan dari masing- masing pertanyaan variabel Produktivitas Kerja memiliki nilai $\mathrm{r}$ hitung lebih besar daripada $\mathrm{r}$ tabel yang memiliki nilai sebesar 0,2213 , sehingga dapat disimpulkan bahwa empat butir pernyataan atau pertanyaan yang ada pada variabel pelaksanaan program pelatihan dinyatakan valid.

\section{HASIL UJI RELIABILITAS}

Tabel 4.3

Uji Reliabilitas

\begin{tabular}{|c|l|c|c|c|}
\hline No & \multicolumn{1}{|c|}{ Variabel } & $\begin{array}{c}\text { Alpha } \\
\text { Croabach }\end{array}$ & Kriteria & Keterangan \\
\hline 1 & Pelaksanaan Program Pelatihan & 0,850 & 0,60 & Reliabel \\
\hline 2 & $\begin{array}{l}\text { Penerapan sistem Manajemen } \\
\text { Keselamatan dan Kesehatan Kerja }\end{array}$ & 0,894 & 0,60 & Reliabel \\
\hline 3 & Produktivitas Kerja & 0,713 & 0,60 & Reliabel \\
\hline
\end{tabular}

Sumber: Olah data SPSS 23, 2021

Hasil uji reliabilitas pada table diatas menunjukkan bahwa bahwa nilai Alpha Cronbach atas variabel pelaksanaan program pelatihan sebesar 0,850 , sistem manajemen keselamatan dan kesehatan kerja sebesar 0,894 dan produktivitas kerja sebesar 0,713 . Dengan demikian dapat disimpulkan bahwa penyataan atau pertanyaan dalam kuesioner ini reliabel karena memiliki nilai Alpha Cronbach > 0,60.

\section{HASIL UJI NORMALITAS}

Tabel 4.4

Uji Normalitas

\begin{tabular}{|c|c|c|}
\hline \multicolumn{3}{|c|}{ One-Sample Kolmogorov-Smirnov Test } \\
\hline & & $\begin{array}{c}\text { Unstandardized } \\
\text { Residual }\end{array}$ \\
\hline \multicolumn{2}{|l|}{$\mathrm{N}$} & 79 \\
\hline \multirow[t]{2}{*}{ Normal Parameters $a, b$} & Mean & .0000000 \\
\hline & Std. Deviation & 1,16724827 \\
\hline \multirow[t]{3}{*}{ Most Extreme Differences } & Absolute & 066 \\
\hline & Positive & 066 \\
\hline & Negative & -.061 \\
\hline \multicolumn{2}{|l|}{ Test Statistic } & .066 \\
\hline \multicolumn{2}{|l|}{ Asymp. Sig. (2-tailed) } & $200=$ \\
\hline \multicolumn{3}{|l|}{ a. Test distribution is Normal. } \\
\hline \multicolumn{3}{|l|}{ b. Calculated from data. } \\
\hline \multicolumn{3}{|c|}{ c. Lilliefors Significance Correction. } \\
\hline \multicolumn{3}{|c|}{ d. This is a lower bound of the true significance. } \\
\hline
\end{tabular}


Pada metode uji Kolmogrov-Smirnov, jika nilai signifikansi $>0,05$ maka variabel berdistribusi normal dan sebaliknya jika signifikansi $<0,05$ maka variabel tidak berdistribusi normal. Dari hasil tabel

4.9 dapat dilihat bahwa nilai Asymp.Sig.(2-tailed) sebesar 0,200>0,05 hal ini membuktikan bahwa data berdistribusi normal.

\section{HASIL UJI MULTIKOLINEARITAS}

Tabel 4.5

Uji Multikolinearitas

\begin{tabular}{|l|l|l|l|}
\hline \multirow{2}{*}{ Variabel Bebas } & \multicolumn{2}{c|}{ Peshituagan } & \multirow{2}{*}{ Keterangan } \\
\cline { 2 - 3 } & \multicolumn{1}{|c|}{ Tolerance } & \multicolumn{1}{|c|}{ VIF } & \\
\hline Pelaksanaan Program Pelatian & 0,615 & 1,626 & $\begin{array}{l}\text { Tidak ada } \\
\text { multikolinieritas }\end{array}$ \\
\hline $\begin{array}{l}\text { Penerapan sistem Manajemen } \\
\text { Keselamatan dan Keschatan } \\
\text { Kerja }\end{array}$ & 0,615 & 1,626 & $\begin{array}{l}\text { Tidak ada } \\
\text { multukolinieritas }\end{array}$ \\
\hline
\end{tabular}

Sumber: Olah data SPSS 23, 2021

Pada tabel diatas dapat diketahui nilai tolerance yang diperoleh masing-masing variabel

pelaksanaan program pelatihan dan penerapan sistem manajemen keselamatan dan kesehatan kerja adalah 0,615 dan nilai VIF sebesar 1,626. Berdasarkan hasil pengujian tersebut dapat disimpulkan bahwa tidak ada multikolinieritas dalam model regresi berganda.

\section{HASIL UJI HETEROSKEDASTISITAS}

Gambar 4.6

Uji Heteroskedasitas

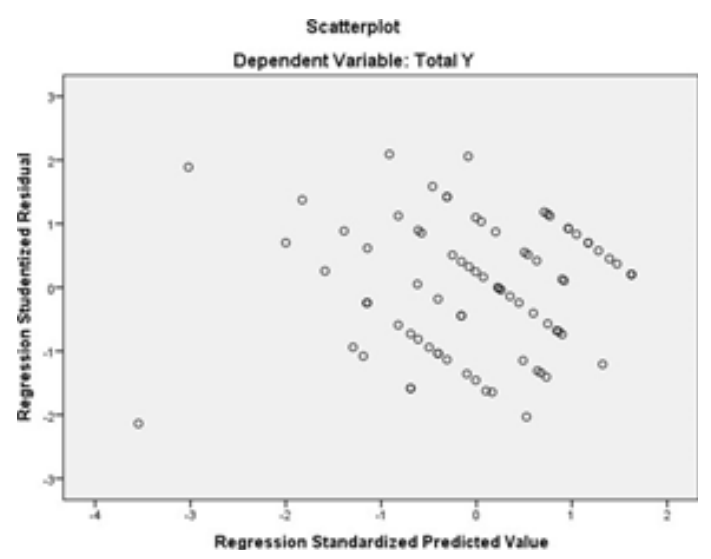

Sumber: Olah data SPSS 23, 2021

Pada gambar diatas menunjukkan bahwa titik-titik menyebar secara acak serta tersebar dengan baik diatas maupun dibawah angka 0 (nol) pada sumbu Y, dan titik-titiknya tersebar secara acak tanpa membentuk pola tertentu, berarti tidak ada gejala heteroskedastisitas dalam model regresi berganda. Sehingga model regresi tersebut layak digunakan untuk memprediksi produktivitas kerja anggota berdasarkan variabel yang mempengaruhinya, yaitu pelaksanaan program pelatihan dan penerapan sistem manajemen keselamatan dan kesehatan kerja.

\section{ANALISIS REGRESI LINIER BERGANDA}

Berdasarkan tabel 4.11 diatas memperoleh persamaan regresi sebagai berikut: $\mathrm{Y}=6,642+0,190$ $\mathrm{X} 1+0,072 \mathrm{X} 2$ model persamaan tersebut memiliki arti bahwa:

1. Konstanta $=6,642$

Memiliki arti bahwa jika variabel pelaksanaan program pelatihan dan penerapan sistem manajemen keselamatan dan kesehatan kerja diasumsikan tidak ada, maka produktivitas kerja anggota memiliki nilai sebesar 6,642.

2. Koefisien Pelaksanaan program pelatihan (X1) Nilai koefisien pelaksanaan program pelatihan sebesar 0,190. Memiliki arti bahwa jika setiap terjadi kenaikan 1 nilai pelaksanaan program pelatihan, maka akan diikuti juga dengan kenaikan produktivitas kerja anggota sebesar 0,190 .

3. Koefisien Penerapan sistem manajemen keselamatan dan kesehatan kerja (X2)

Nilai koefisien penerapan sistem manajemen keselamatan dan kesehatan kerja sebesar 0,072. Memiliki arti bahwa jika setiap terjadi kenaikan 1 nilai penerapan sistem manajemen keselamata dan kesehatan kerja, maka akan diikuti juga dengan kenaikan produktivitas kerja anggota sebesar 0,072 .

\section{UJI HIPOTESIS}

Tabel 4.8

Hasil Uji F

\begin{tabular}{|c|c|c|c|c|c|c|}
\hline \multicolumn{7}{|c|}{ ANONA' } \\
\hline \multicolumn{2}{|c|}{ Model } & Sum of Squares & df & Mean Square & $\mathrm{F}$ & Sig. \\
\hline \multirow[t]{3}{*}{1} & Regression & 123,601 & 2 & 61.800 & 4,196 & $.000^{\circ}$ \\
\hline & Residual & 106.273 & 76 & 1,358 & & \\
\hline & Total & 229.873 & 78 & & & \\
\hline
\end{tabular}

a. Dependent Varisale Total Y

D. Predictors: (Constant). Total X2, Total X1

Sumber: Olah data SPSS 23, 2021

Berdasarkan tabel diatas dapat diketahui jika diperoleh nilai F hitung sebesar 44,196 > 3,12 (F tabel) dengan nilai sig. 0,000 $<0,05$ (5ØüP) atau nilai signifikan kurang dari 0,05. Maka dari itu Ho ditolak dan Ha diterima yang berarti bahwa secara simultan 
Pelaksanaan Program Pelatihan (X1) dan Penerapan sistem manajemen keselamatan dan kesehatan kerja (X2) berpengaruh secara signifikan terhadap produktivitas kerja anggota $(\mathrm{Y})$.

Tabel 4.9

Hasil Uji T

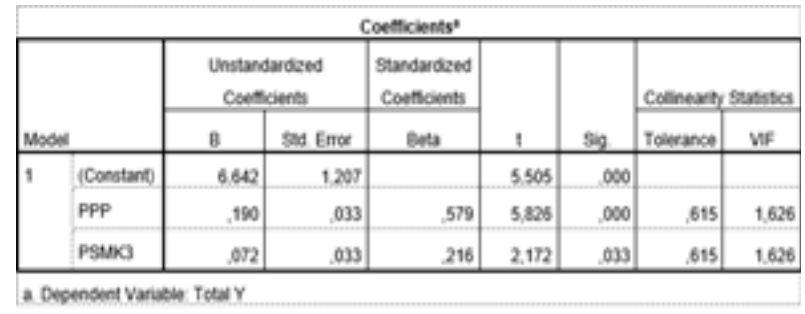

Sumber: Olah data SPSS 23, 2021

Dari hasil tabel diatas dapat diketahui untuk variabel Pelaksanaan Program Pelatihan (X1) diperoleh nilai t-hitung sebesar 5,826 >1,66515 (t tabel) dengan sig. 0,000 < 0,05 ( 5ØüP) atau nilai signifikan lebih kecil dari 0,05. Maka dari itu Ho ditolak atau Ha diterima yang berarti secara parsial pelaksanaan program pelatihan (X1) berpengaruh signifikan terhadap produktivitas kerja (Y).

Untuk variabel pelaksanaan sistem manajemen keselamatan dan kesehatan kerja (X2) diperoleh thitung sebesar 2,172>1,66515 (t table) dengan sig. $0,033<0,05$ (5ØüP) atau nilai signifikan lebih kecil dari 0,05. Maka dari itu Ho ditolak atau Ha diterima yang berarti secara parsial penerapan sistem manajemen keselamatan dan kesehatan kerja (X2) berpengaruh signifikan terhadap produktivitas kerja (Y).

\section{UJI KOEFISIEN DETERMINASI}

Tabel 4.10

Hasil Uji Koefisien Determinasi

\begin{tabular}{|c|c|c|c|c|}
\hline \multicolumn{5}{|c|}{ Model Summary } \\
\hline Model & $\mathbf{R}$ & R Square & $\begin{array}{l}\text { Adjusted R } \\
\text { Square }\end{array}$ & $\begin{array}{l}\text { Std. Error of the } \\
\text { Estimate }\end{array}$ \\
\hline 1 & $.733^{\circ}$ & .538 & .526 & 1,183 \\
\hline
\end{tabular}

Sumber: Olah data SPSS 23, 2021

Berdasarkan pada tabel memperoleh nilai $\mathrm{R}$ Square sebesar 0,538 atau $53,8 \%$. Hal ini menunjukkan bahwa produktivitas kerja anggota dapat menjelaskan variasi dari dua variabel independen, yaitu pelaksanaan program pelatihan dan penerapan sistem manajemen keselamatan dan kesehatan kerja sebesar 53,8\%. Sedangkan 46,2\% dijelaskan oleh sebab-sebab lain yang ada diluar variabel pada penelitian ini seperti variabel disiplin menggunakan alat pelindung diri dan lingkungan kerja.

\section{KESIMPULAN}

Berdasarkan pembahasan dan analisa, hasil penelitian yang dilakukan dapat disimpulkan sebagai berikut:

1. Berdasarkan hasil dari penelitian ini menyatakan bahwa pelaksanaan program pelatihan berpengaruh positif dan signifikan terhadap produktivitas kerja anggota pada dinas pemadam kebakaran kota Bekasi yang mana dapat dilihat dari tabel 4.9 hasil t-hitung sebesar 5,826 > 1,66515 (t tabel) dengan sig. 0,000 $<0,05$ (5ØüP) atau nilai signifikan lebih kecil dari 0,05. Maka dari itu pelaksanaan program pelatihan sangat berpengaruh bagi para anggota dinas pemadam kebakaran kota Bekasi yang sangat menentukan para anggota dapat menjalankan tugas secara efektif dan efesien, sehingga berpengaruh terhadap produktivitas kerja anggota dalam menyelesaikan suatu pekerjaan.

2. Berdasarkan hasil dari penelitian ini menyatakan bahwa penerapan sistem manajemen keselamatan dan kesehatan kerja (K3) berpengaruh positif dan signifikan terhadap produktivitas kerja anggota pada dinas pemadam kebakaran kota Bekasi yang mana dapat dilihat dari tabel 4.9 hasil t-hitung sebesar 2,172 > 1,66515 (t table) dengan sig. 0,033 $<0,05$ (5ØüP) atau nilai signifikan lebih kecil dari 0,05. Maka dari itu penerapan sistem manajemen keselamatan dan kesehatan kerja sangatlah penting dalam suatu organisasi, karena pada dinas pemadam kebakaran kota Bekasi memiliki tingkat risiko kecelakaan yang tinggi, maka siste manajemen keselamatan dan kesehatan kerja (K3) anggota perlu ditinkatkan. Hal ini dilakukan untuk meningkatkan produktivitas kerja angggota.

3. Berdasarkan hasil uji $\mathrm{F}$ pada tabel 4.8 yang menyatakan bahwa pelaksanaan program pelatihan dan penerapan sistem manajemen keselamatan dan kesehatan kerja (K3) secara simultan berpengaruh signifikan terhadap produktivitas kerja anggota pada dinas pemadam kebakaran kota Bekasi, yang mana uji $\mathrm{F}$ menunjukkan F-hitung sebesar 44,196> 3,12 (F tabel) dengan nilai sig. 0,000 <0,05 (5Øӥ̈) atau nilai signifikan kurang dari 0,05 . Maka dari itu Ho ditolak dan Ha diterima yang berarti bahwa 
secara simultan Pelaksanaan Program Pelatihan (X1) dan Penerapan sistem manajemen keselamatan dan kesehatan kerja (X2) berpengaruh secara signifikan terhadap produktivitas kerja anggota (Y). Dapat disimpulkan bahwa pelaksanaan program pelatihan merupakan suatu hal yang sangat penting agar para anggota dapat menjalankan dan menyelesaikan tugas secara efektif dan efisien sehingga produktivitas kerja anggota pun meningkat. Dan dinas pemadam kebakaran kota Bekasi perlu menerapkan sistem manajemen keselamatan dan kesehatan kerja (K3) dengan menyediakan perlengkapan atau alat-alat (K3) untuk mengurangi kasus kecelakaan pada anggota, menjamin keselamatan dan kesehatan para anggota saat melaksanakan tugas.

\section{IMPLIKASI MANAJERIAL}

Berdasarkan hasil penelitian dan kesimpulan diatas, maka penulis memberikan beberapa masukkan yang bermanfaat untuk anggota dinas pemadam kebakaran kota Bekasi yang berkaitan dengan pelaksanaan program pelatihan, penerapan sistem manajemen keselamatan dan kesehatan kerja (K3) dan produuktivitas kerja anggota dimasa yang akan datang yakni sebagai berikut:

1. Bagi Penulis

Diharapkan dengan adanya penelitian ini dapat menambah wawasan dan dapat digunakan sebagai implementasi keilmuan penulis.

2. Bagi Instansi

Hasil penelitian ini dapat dijadikan masukan dan bahan pertimbangan bagi dinas pemadam kebakaran kota Bekasi untuk lebih mingkatkan pelatihan dan mengutamakan keselamatan dan kesehatan kerja anggota untuk mencapai produktivitas kerja yang optimal.

3. Bagi Universitas

Penelitian ini diharapkan dapat menjadi referensi untuk penelitian selanjutnya dan dapat memperdalam dampak mengenai pelaksanaan program pelatihan dan efektivitas sistem manajemen keselamatan dan kesehatan kerja terhadap produktivitas kerja anggota organisasi atau perusahaan.

4. Bagi Peneliti Selanjutnya

Diharapkan untuk peneliti selanjutnya memasukkan variable independen lainnya dan menambah jumlah responden, sehingga memperoleh informasi mengenai factor-faktor lainnya yang mempengaruhi produktivitas kerja.

\section{DAFTAR PUSTAKA}

Afif, E. R., 2019. Pengaruh Lingkungan Kerja, K3 Dan Pelatihan Terhadap Produktivitas Kerja Pada Pt Gt-Pro. Jurnal Ilmu dan Riset Manajemen, pp. 1-18.

Bangun, W., 2017. Manajemen SDM Hubungan Industrial. Jakarta: Erlangga.

Dessler, G., 2015. Manajemen Sumber Daya Manusia. Jakarta: Salemba Empat.

Hairo, A. M. \& Martono, S., 2019. The Effect of Environment, Training, Motivation, and Satisfaction on Work Productivity. Management Analysis Journal, pp. 50 - 57.

Hedianto, B. R., Mukzam, M. D. \& Iqbal, M., 2014. Pengaruh Keselamatan Dan Kesehatan Kerja (K3) Terhadap Motivasi Kerja Karyawan (Studi pada Karyawan bagian Drilling \& Oilfield Services PT Elnusa Tbk. Jakarta). Jurnal Administrasi Bisnis S1 Universitas Brawijaya.

Mangkunegara, A. A. P., 2015. Manajemen Sumber Daya Manusia Perusahaan. Bandung: Remaja Rosdakarya.

Purwati, S., Sitepu, M. \& Panjaitan, F., 2017. Analisis Pengaruh Penerapan Sistem Manajemen Keselamatan Dan Kesehatan Kejra (K3) Terhadap Produktivitas Kerja Karyawan (Studi Kasus Pada PT Timah (Persero) Tbk). Jurnal Ilmiah Progresif Manajemen Bisnis (JIPMB), Volume Volume 20.

Sofyandi, H., 2013. Manajemen Sumber Daya Manusia. Yogyakarta: Graha Ilmu.

Sugiyono, 2016. Metode Penelitian Kuantitatif Kualitatif Dan R\&D. Bandung: Alfabeta.

Sujarweni, V. W., 2015. Statistik Untuk Bisnis Dan Ekonomi. Yogyakarta: Pustaka Baru Press.

Sujarweni, V. W., 2018. Metodologi Penelitian Bisnis Dan Ekonomi Pendekatan Kuantitatif. Yogyakarta: Pustaka Baru Press.

Suparyadi, 2015. Manajemen Sumber Daya Manusia : Menciptakan Keunggulan Bersaing Berbasis Kompetensi SDM. Yogyakarta: Andi.

Sutrisno, E., 2015. Manajemen Sumber Daya Manusia. Jakarta: Kencana Prenadamedia Group.

Widodo, E. S., 2015. Manajemen Pengembangan Sumber Daya Manusia. Yogyakarta: Pustaka Pelajar.

Zainal, V. R., 2014. Manajemen Sumber Daya Manusia Untuk Perusahaan Dari Teori Ke Praktek. Jakarta: Rajawali Pers 
